\title{
DAMPAK BEAUTIFUL MALINO SEBAGAI PROGRAM UNGGULAN DALAM MENDONGKRAK SEKTOR PARIWISATA DI KABUPATEN GOWA, SULAWESI SELATAN
}

\author{
Arsul Sarif*); Muh. Hasrul; A. Lukman Irwan \\ Universitas Hasanuddin \\ *)email: arsulsyarif97@gmail.com
}

Paper Accepted: 27 Maret 2021 Paper Reviewed: 28-31 Maret 2021 Paper Edited: 01-15 April 2021 Paper Approved: 26 April 2021

\begin{abstract}
ABSTRAK
Selama tiga hari digelar, Beautiful Malino mencatat jumlah transaksi di kawasan wisata Malino mencapai Rp28 miliar. Kepala Dinas Pariwisata dan Kebudayaan Gowa Sophian Hamdi mengatakan, nilai ini merupakan estimasi dari jumlah pengunjung yang datang di Beautiful Malino. Tentunya perputaran uang yang cukup besar ini akan meningkatkan income perkapita masyarakat bukan hanya di Malino. Dalam memperoleh data yang relevan dengan tema penelitian, maka penelitian ini menggunakan metode kualitatif dengan model deskriptif. Yaitu penelitian yang menggambarkan atau melukiskan situasi tertentu berdasarkan data yang diperoleh sesuai dengan permasalahan yang ditetapkan dalam penelitian ini. Hasil wawancara akan dikolaboratif dengan hasil kuisioner. Lokasi dalam penelitian ini adalah Kabupaten Gowa, terutama kelompok pemuda, Dinas Pemuda dan Olahraga, Dinas Pariwisata dan Kebudayaan, serta instansi yang memiliki keterkaitan pengembangan program kepemudaan Kabupaten Gowa. Lokasi penelitian ini ditentukan secara purpossive. Beautiful Malino setidaknya memberikan dampak yang positif terhadap sektor pariwisata di Sulawesi Selatan khususnya di Kabupaten Gowa. Beautiful Malino, belum memberikan dampak signifikan terhadap sejumlah objek wisata sejarah dan budaya yang terdapat di Kota Malino. Hal ini disebabkan karena tidak terawatnya situssitus sejarah dan budaya yang ada di kawasan Malino. Perlu adanya peningkatan infrastruktur pendukung seperti perbaikan jalan serta lainnya di kawasan wisata Malino yang menjadi pendukung.
\end{abstract}

Kata kunci: Beautiful Malino, Pemda Gowa, Program Unggulan

\section{PENDAHULUAN}

Pelestarian dan pengembangan kebudayaan pariwisata memiliki tujuan untuk menimbulkan pemahaman dan perngembangan di masyarakat terhadap kebudayaan dan pariwasata, meningkatkan kualitas serta menumbuhkan sikap kritis. Pembangunan bidang pariwasata dan kebudayaan memiliki peran penting dalam memperbaiki struktur kehidupan bangsa iseperti persoalan yang bersifat multidimensional yang masih berlanjut. Jumlah kunjungan wisatawan mancanegara (wisman) ke Indonesia sepanjang periode Januari hingga Agustus 2019 mencapai 10,87 juta kunjungan atau naik 8,19 persen dibanding jumlah kunjungan wisman pada periode yang sama tahun sebelumnya, yang berjumlah 2,30 juta kunjungan.

Jumlah kunjungan wisatawan mancanegara atau wisman ke Indonesia pada Februari 2019 mencapai 1,27 juta kunjungan, mengalami kenaikan sebesar 6,12 persen dibanding jumlah kunjungan wisman pada Februari 2018 yang berjumlah 1,20 juta kunjungan. Begitu pula, jika dibandingkan dengan Januari 2019, jumlah kunjungan wisman Februari 2019 mengalami kenaikan sebesar 4,80 persen. Jumlah kunjungan wisatawan mancanegara atau wisman ke Indonesia Februari 2019 naik 6,12 persen dibanding jumlah kunjungan pada 
Februari 2018, yaitu dari 1,20 juta kunjungan menjadi 1,27 juta kunjungan. Begitu pula, jika dibandingkan dengan Januari 2019, jumlah kunjungan wisman pada Februari 2019 mengalami kenaikan sebesar 4,80 persen. Secara kumulatif (Januari-Februari 2019), jumlah kunjungan wisman ke Indonesia mencapai 2,48 juta kunjungan atau naik 8,19 persen dibandingkan dengan jumlah kunjungan wisman pada periode yang sama tahun 2017 yang berjumlah 2,30 juta kunjungan.

Sulawesi Selatan memiliki potensi pariwisata yang cukup besar. Dengan latar budaya yang berbeda-beda, keragaman topografi dan keindahan alam, serta dukungan fasilitas yang memadai menjadikan wilayah ini salah satu destinasi wisata. Kegiatan kepariwisataan diharapkan mampu menjadi salah satu kekuatan pembangunan yang dapat diandalkan. Sektor pariwisata merupakan invisible export karena kemampuannya mendatangkan manfaat bagi pendapatan daerah maupun pendapatan masyarakat yang tentunya akan berdampak pada peningkatan pertumbuhan ekonomi. Kontribusi pariwisata terhadap pemerintah terbagi atas dua yaitu: kontribusi lansung dan kontrubusi tidak lansung, kontribusi lansung berasal dari pajak pendapatan yang dipungut dari para pekerja pariwisata dan pelaku bisnis pariwisata.

Sedangkan kontribusi tidak lansung terhadap pendapatan daerah bersumber dari pajak dan bea cukai barang-barang yang diimpor serta dan pajak yang dikenakan kepada wisatawan pengunjung. Efek dari pariwasata terhadap pertumbuhan ekonomi adalah menghasilkan devisa yang cukup besar yang bermanfaat bagi pendanaan pembangunan dan pemerataan ekonomi kerakyatan. Seiring pertambahan jumlah kunjungan wisatawan akan berdampak pada investasi infrastruktur. Infrastruktur di bidang transportasi, komunikasi, akomodasi, dan jasa-jasa lainnya akan berkembang pesat. Pariwisata mendorong perkembangan industri-industri lainnya, baik secara langsung, tidak langsung maupun efek stimulasi.

Ekonomi kreatif, ekonomi kerakyatan dan ekonomi digital akan berkembang pesat dengan bertumbuhnya pariwisata. Pariwisata akan membuka pangsa pasar bagi produk lokal.Pariwisata memberikan kontribusi untuk menciptakan lapangan kerja dan meningkatkan pendapatan.Statistik kunjungan wisatawan mancanegara ke Sulawesi Selatan menunjukkan tren yang meningkat selama beberapa tahun terakhir, namun memasuki tahun 2018 terjadi penurunan jumlah wisatawan mancanegara.
Menyikapi hal ini perlu dilakukan berbagai upaya perbaikan untuk menjadikan pariwisata sebagai leading sector.

Undang-undang Republik Indonesia Nomor 10 Tahun 2009 tentang Kepariwisataan menyatakan bahwa kepariwisataan bertujuan antara lain untuk meningkatkan pertumbuhan ekonomi, meningkatkan kesejahteraan rakyat, menghapus kemiskinan, mengatasi pengangguran, memajukan kebudayaan, dan mengangkat citra bangsa. Dalam rencana pembangunan jangka menengah nasional (RPJMN) 2015-2019 juga disebutkan bahwa pembangunan pariwisata diarahkan sebagai sektor andalan, yang mampu menjadi salah satu sektor penghasil devisa, mendorong pertumbuhan ekonomi, meningkatkan pendapatan daerah, memberdayakan perekonomian masyarakat, serta memperluas kesempatan kerja.

Seiring peningkatan jumlah kunjungan wisatawan di Sulawesi Selatan maka upaya peningkatan pelayanan terkait pelayanan jasa akomodasi kepada wisatawan perlu diperhatikan. Perencanaan pembangunan, penambahan jumlah kamar hotel dan akomodasi lainnya, serta peningkatan ragam dan kualitas layanan harus senantiasa diupayakan.

Hal ini mengingat akomodasi merupakan faktor yang sangat penting bagi wisatawan yang mengharapkan kenyamanan, pelayanan yang baik, kebersihan dan lain- lain. Memajukan industri pariwisata menjadi salah satu program strategis Pemerintah Provinsi Sulawesi Selatan. Guna mewujudkan itu, seluruh kabupaten/kota di Sulsel dituntut untuk membangun sinergi dan mendorong hadirnya beragam inovasi di sektor pariwisata. Kabupaten Gowa misalnya, menghadirkan even wisata yang diyakini mampu menggenjot sektor pariwisata di daerah berjuluk "Butta Bersejarah" itu. Beautiful Malino, sebuah event wisata yang digagas Pemkab Gowa dinilai memberi dampak signifikan terhadap kunjungan wisatawan di Kabupaten Gowa.

Menanggapi itu, Gubernur Sulsel Nurdin Abdullah menyatakan seluruh rencana Pemkab Gowa itu juga menjadi tanggung jawab Pemprov Sulsel. Pemerintah provinsi siap menyinergikan program kabupaten/kota di Sulsel. Pembenahan infrastruktur guna mendorong sektor pariwisata di Gowa ini juga menjadi tugas kami Pemprov Sulsel, karena ini juga masuk dalam program strategis. Selain infrastruktur jalan, Pemprov sul-sel juga menyatakan siap membantu Pemkab Gowa melanjutkan usulan ke Kementerian Lingkungan Hidup untuk menjadikan hutan 
Pinus agar bisa menjadi aset daerah. Pemprov optimistis seluruh rencana itu bisa rampung pada 2021 mendatang.

Selama tiga hari digelar, Beautiful Malino mencatat jumlah transaksi di kawasan wisata Malino mencapai Rp28 miliar. Kepala Dinas Pariwisata dan Kebudayaan Gowa Sophian Hamdi mengatakan, nilai ini merupakan estimasi dari jumlah pengunjung yang datang di Beautiful Malino. Tentunya perputaran uang yang cukup besar ini akan meningkatkan income perkapita masyarakat bukan hanya di Malino. Event wisata Beautiful Malino 2019 ini mengalami peningkatan yang cukup besar jika dibandingkan pelaksanaan di tahun-tahun sebelumnya. Pada target awal pihaknya hanya menargetkan sebanyak 60 ribu pengunjung atau seperti pencapaian tahun lalu. Hanya saja, sesuai data dan laporan petugas di lapangan ternyata jumlah pengunjung (wisatawan) yang hadir sampai saat ini telah mencapai angka sekitar 70 ribu. Oleh karena itu pemerintah gowa berharap dukungan dari berbagai pihak agar mampu di gelar secara rutin dalam tiap tahun,serta program ini telah di ajukan oleh Pemkab Gowa kepada Kementrian Pariwasata.

\section{Rumusan Masalah}

Jumlah kunjungan bahkan meningkat hingga 100 persen-pasca digelarnya event wisata yang berpusat di Malino, Kecamatan Tinggimoncong, Gowa. Event tersebut juga dinilai berdampak terhadap income masyarakat sekitar yang membuka usaha oleh-oleh khas daerah. Sayangnya, pertumbuhan itu tak sejalan dengan aksesibilitas di kawasan wisata yang di dorong menjadi brand untuk mengubah wajah Gowa. Infrastruktur jalan yang belum memadai menjadi salah satu kendala yang masih ditemui pengunjung hingga tahun ketiga digelarnya Beautiful Malino. Kemacetan masih terjadi di sejumlah ruas jalan. Apalagi selama puncak acara event Beautiful Malino berlangsung. Sejumlah titik jalan juga masih mengalami kerusakan dan belum tersentuh pemerintah. Melihat fenomena itu, Pemkab Gowa berjanji akan segera membenahi infrastruktur di sejumlah ruas jalan di Kecamatan Tinggimoncong. Sebab, sejauh ini pembangunan baru dilakukan di Jalan Poros Makassar-Malino. Pemkab gowa pada tahun 2018 telah merevitalisasi jalan poros Malino dengan anggaran Rp75 milar dari Kementerian PUPR untuk pelebaran sepanjang 15 kilometer.

Diketahui, untuk menuju kawasan wisata Malino, pengunjung harus menempuh jalur kurang lebih 63 kilometer dengan waktu tempuh berkisar dua jam. Pemkab Gowa berupaya memangkas jarak tempuh menuju Malino dari Makassar menuju Kota Malino dengan menempuh jarak tempuh 45 menit saja. Olehnya itu Pemkab Gowa merencanakan pengerjaan infrastuktur berlanjut pada 2020. Selain itu, Pemkab Gowa juga berkomitmen akan segera melakukan revitalisasi di kawasan hutan Pinus Malino yang notabene merupakan lokasi utama digelarnya Beautiful Malino. Hutan Pinus yang juga menjadi salah satu ikon di Malino akan direkomendasikan pada Kementerian Lingkungan Hidup untuk dijadikan sebagai aset daerah. Pada 2018 lalu, Pemkab Gowa telah menganggarkan Rp6 miliar untuk revitalisasi hutan Pinus. Namun, setelah dilakukan pengecekan ternyata hutan Pinus bukanlah aset daerah. Sehingga perlu mengajukan rekomendasi kepada Kementerian Lingkungan Hidup terlebih dulu.

\section{METODE PENELITIAN}

Dalam memperoleh data yang relevan dengan tema penelitian, maka penelitian ini menggunakan metode kualitatif dengan model deskriptif. Yaitu penelitian yang menggambarkan atau melukiskan situasi tertentu berdasarkan data yang diperoleh sesuai dengan permasalahan yang ditetapkan dalam penelitian ini. Hasil wawancara akan dikolaboratif dengan hasil kuisioner. Lokasi dalam penelitian ini adalah Kabupaten Gowa, terutama kelompok pemuda, Dinas Pemuda dan Olahraga, Dinas Pariwisata dan Kebudayaan, serta instansi yang memiliki keterkaitan pengembangan program kepemudaan Kabupaten Gowa. Lokasi penelitian ini ditentukan secara purpossive.

Penelitian ini akan berlangsung dari Agustus hingga Maret 2020. Penelitian ini berlokasi di Kelurahan Malino yang secara administrasi berada pada Kecamatan Tinggi Moncong, Kabupaten Gowa. Pemilihan lokasi ini dikarenakan pada kecamatan tersebut adalah lokasi kegiatan program unggulan. Menurut Suparlan (dalam Basuki, 2006) metode pengamatan digunakan untuk memperoleh informasi mengenai gejala-gejala yang dalam kehidupan sehari-hari dapat diamati. Hasil pengamatan biasanya didiskusikan oleh si peneliti dengan warga masyarakat yang bersangkutan untuk mengetahui makna yang terdapat dibalik gejala-gejala tersebut.

Peneliti akan melakukan pengamatan pada aktivitas pemuda, pelatihan, situasi program berjalan, usaha-usaha yang digeluti dan berbagai aktivitas kepemudaan yang berkaitan 
dengan topik penelitian. Observasi juga dilakukan untuk mengetahui keadaan lingkungan kecamatan, desa, jarak tempuh dari kota hingga pembangunan titik usaha baru.

Sumber data penelitian ini terbagi menjadi dua yaitu data primer dan data sekunder. Data primer adalah data yang diperoleh peneliti secara langsung informan melalui wawancara dan angket yang telah disebarkan. sementara data sekunder adalah data yang diperoleh peneliti dari sumber yang sudah ada. Contoh data sekunder misalnya catatan atau dokumentasi perusahaan berupa absensi, Laporan bulanan dan tahunan dari dinas-dinas terkait, laporan keuangan publikasi dinas, laporan pemerintah, data yang diperoleh dari buku majalah, dan lain sebagainya. Dalam memperoleh data yang relevan dengan topik penelitian dilakukan dengan beberapa cara yaitu sebagai berikut; wawancara, observasi, dan dokumentasi.

Wawancara tidak saja dilakukan secara formal, tetapi juga wawancara secara bebas. Pada awalnya ketika memasuki lapangan penulis menggunakan wawancara bebas. Hal ini dimaksudkan sebagai strategi pendekatan terhadap informan (rapport) selanjutnya wawancara individual dilakukan secara mendalam. Wawancara adalah upaya untuk mendapatkan data dari responden. Dimana dilakukan untuk mendapatkan tujuan dari diadakannya penelitian. Menurut Nazir (1988) adalah proses memperoleh keterangan untuk tujuan penelitian dengan cara tanya jawab sambil bertatap muka antara peneliti atau pewawancara dengan informan atau responden dengan menggunakan alat yang dinamakan interview guide (panduan wawancara). Adapun topik-topik wawancara meliputi berbagai topik seperti aktivitas pemuda dalam kesehariannya, motivasi hidup, tingkat pendidikan, skill, pengalaman kerja, keinginan berwirausaha, bentuk respon program pemerintah dan lain-lain yang berkaitan dengan topik penelitian. Topik wawancara akan berkembang seiring dengan hadirnya kasus-kasus yang dianggapp penting untuk dikaji.

Observasi merupakan proses pengamatan terhadap suatu fenomena berkaitan dengan aktivitas suatu kelompok masyarakat. Observasi dilakukan untuk memperoleh Kuisioner. Kuisioner merupakan metode pengumpulan data yang dilakukan dengan cara memberi seperangkat pertanyaan atau pernyataan tertulis kepada responden untuk dijawab. Dalam penelitian ini peneliti hanya menggunakan kuisioner tertutup yaitu kuisioner yang telah menyediakan jawaban atas pertanyaan atau pernyataan yang disediakan.

Dokumentasi menjadi salah satu alternatif dalam mengeksplor hasil penelitian ini. Hasil wawancara dan observasi telah diabadikan dalam bentuk visual (rekaman, foto dan lainlain). Hal ini akan menjadi bukti hasil penelitian dan akan membantu pada proses analisa data.

\section{HASIL DAN PEMBAHASAN}

Program Beautiful Malino di Kabupaten Gowa merupakan salah satu program unggulan Bupati Gowa periode 2016-2021 Adnan Purichta Ichsan YL. Sektor Pariwisata memang menjadi daya tarik bagi peningkatan Pendapat Asli Daerah (PAD). Kabupaten Gowa yang terdiri dari atas dataran tinggi dan rendah menjadi sebuah potensi untuk dikembangkan.

Salah satu kawasan wisata yang sudah populer sejak dahulu adalah Malino. Kawasan ini memiliki icon hutan pinus dan kesejukannya. Berbagai segmen tempat wisata ada di dalamnya, mulai dari air terjun, kebun strawberry, kebun teh, kolam renang, tempat camp yang menjadi magnet bagi wisatawan. Untuk membangkitkan kembali gairah pariwisata di Malino maka Pemkab Gowa mengemas sebuah kegiatan yang bertajuk Beautiful Malino sebagai agenda tahunan.

Dikutip dari idn-times (2019) menyebut event pariwisata utama milik Pemkab Gowa itu sudah masuk edisi ketiga setelah pertama kali diadakan pada tahun 2017 silam. Berpusat di Kawasan Hutan Pinus Malino, Kecamatan Tinggimoncong, Gowa, acara ini mengajak para pengunjung dan undangan merasakan langsung hawa dingin khas lembah. Penduduk Makassar pun tak harus jauh-jauh menuju Bogor, Batu di Malang atau Kaliurang di Yogyakarta. Cukup berkendara selama dua jam lebih dari Makassar, dan wisatawan siap disambut suasana asri nan tenang.

Beautiful Malino digagas sebagai usaha Pemkab Gowa memajukan potensi pariwisata. Beautiful Malino pertama kali digodok Pemkab Gowa melalui Dinas Pariwisata dan Kebudayaan Kabupaten Gowa pada awal tahun 2017. Kawasan Tinggimoncong, yang selama ini jadi primadona masyarakat Kota Makassar jika hendak melarikan diri dari penatnya rutinitas, coba dikenalkan ke publik nasional. Jika Makassar terkenal dengan wisata pantai dan Maros berkat bukit karst eksotis, Gowa hendak menonjolkan lanskap lembah nan menyejukkan. Belum lagi jika berbicara tentang kebun teh, hutan Pinus hingga kebun bunga di Malino yang menjadi spot andalan bagi mereka 
yang doyan ber-swafoto. Ini sejalan dengan agenda Bupati Adnan Purichta Ichsan dan Wabup Abdul Rauf Malaganni Kr Kio yang ingin memasukkan nama Malino dalam daftar destinasi wisata nasional. Edisi pertama dihelat pada 14-15 Juli 2015, Beautiful Malino langsung dimasukkan dalam kalender event tahunan provinsi Sulawesi Selatan.

\section{Rutin Hadirkan Musisi Papan Atas Indonesia}

Beautiful Malino terdiri atas beberapa acara yakni karnaval budaya, pameran pembangunan, lomba sepeda gunung, lari lintas alam, lomba foto, summer camp, dan penampilan sejumlah musisi nasional. Sejumlah lahan rutin disediakan bagi para pengunjung yang hendak menikmati rangkaian event sembari berkemah. Yang menyedot atensi publik tentu saja roster musisi yang datang langsung ke Malino menghibur pengunjung tiap tahunnya.

Pada edisi perdana 2017, panitia mengundang Adi eks-Naff, Musikimia proyek sampingan personel Padi sebelum reuni serta Andra and the Backbone. Setahun berselang, 2018, giliran Pusakata --band bentukan Is usai hengkang dari Payung Teduh, D'Masiv dan Kotak sebagai penampil utama. Tradisi hadirkan band rock tetap dipertahankan meski pada tahun ini musisinya lebih beragam, musisi yang diundang pun lebih banyak. Sejumlah band indie lokal kebagian merasakan manggung di Lembah Malino seperti Kapal Udara, Natinson dan Senjanada. Ada juga Jad N Sugy, jebolan ajang pencarian bakat X Factor Indonesia. Gigi dan penyanyi solo Andmesh Kamaleng didapuk sebagai main guest Beautiful Malino 2019.

\section{Berdampak Positif pada Pelaku UMKM}

Meski alokasi dana dari APBD tak berubah yakni hanya Rp1 miliar, Pemkab Gowa optimistis jika angka pengunjung Beautiful Malino kembali naik signifikan. Saat edisi perdana hanya menggaet 30 ribu pengunjung, angka menanjak menjadi 60 ribu orang helatan tahun 2018. Target pun dipatok lebih tinggi yakni 100 ribu, didasarkan pada fakta jika tren antusiasme publik meningkat. Dengan anggaran "seadanya", dampak ekonomi justru paling dirasakan pelaku usaha kecil dan menengah yang bertebaran di sekitar kawasan wisata tersebut.

Contohnya para pengelola villa, homestay hingga UMKM yang bergerak di sektor kuliner. Tahun lalu pihak penyelenggara mencatat jika total transaksi mencapai Rp24 miliar. Plt Kabag Humas dan Kerjasama Pemkab Gowa, Abdullah Sirajuddin, menyuarakan rasa optimis jika Beautiful Malino sudah layak masuk dalam agenda nasional milik Kementerian Pariwisata. Ia merujuk pada gelaran yang sudah dihelat tiga tahun berturut-turut, infrastruktur pendukung, aksesibilitas dan masih banyak lagi. Pariwisata memiliki peran besar dalam pembangunan nasional dan memiliki peran penting dalam perekonomian Indonesia, karena pariwisata merupakan salah satu penghasil devisa bagi negara Indonesia (Rani, 2014).

Hal ini dibuktikan dengan jumlah kunjungan wisatawan yang mengalami pertumbuhan sebesar 15,54 persen yang berkontribusi terhadap penerimaan devisa sebesar Rp176 triliun rupiah (Laporan Kinerja Kementrian Pariwisata, 2017). Pada saat ini, pariwisata telah berkontribusi kurang lebih sebanyak empat persen pada perekonomian di Indonesia dan ditargetkan akan mencapai delapan persen tahun 2019 (Indonesia Investment, 2019).

Saat ini, trending minat kunjungan perjalanan wisata yang sebelumnya konvensional telah beralih menjadi minat khusus, di antaranya adalah lingkungan, alam, budaya, sejarah dan atraksi wisata lainnya yang tentu saja sesuai dengan motivasi perjalanan wisatawan dalam melakukan perjalanan wisata (Priyanto \& Safitri, 2016). Sesuai dengan kebijakan pengembangan pariwisata nasional dengan fokus pengembangan pada daya tarik wisata (Bidarab, dkk, 2017), maka pemerintah Kabupaten Gowa tengah menaruh perhatian lebih kepada potensi-potensi daya tarik wisata yang dimilikinya.

Letak ibu kota daerah Kabupaten Gowa yang berbatasan langsung dengan ibu kota provinsi Sulawesi Selatan, Kota Makassar memberikan keuntungan tersendiri. Selama tahun 2017 sampai awal tahun 2018 jumlah wisatawan nusantara dan mancanegara yang datang mengunjungi obyek wisata yang ada di Kabupaten Gowa mengalami peningkatan dari 49.410 menjadi 55.506 wisatawan (Badan Pusat Statistik Kabupaten Gowa, 2018). Berdasarkan data tersebut dapat dilihat bahwa jumlah wisatawan yang mengunjungi daya tarik wisata yang ada di Kabupaten Gowa, baik itu wisatawan nusantara maupun mancanegara mengalami fluktuasi yang signifikan.

Kunjungan wisatawan tertinggi terjadi pada tahun 2015 dengan jumlah wisatawan mencapai 105.584 orang dengan peningkatan sebesar 58 persen dari tahun sebelumnya, kemudian mengalami penurunan pada tahun 2016 menjadi 
56 persen dengan jumlah kunjungan wisatawan hanya 49.409 orang. Kemudian kembali mengalami peningkatan sebanyak sebesar enam persen pada tahun 2017 dengan jumlah kunjungan wisatawan sebesar 55.506 orang. Pemerintah Kabupaten Gowa tengah membuat beberapa program untuk mengembangkan daya tarik wisatanya. Hal ini bertujuan untuk lebih meningkatkan kunjungan wistawan ke Kabupaten Gowa, baik itu wisatawan nusantara maupun mancanegara. Salah satu program pemerintah Kabupaten Gowa yang tengah dijalankan adalah Beautiful Malino yang merupakan program pemerintah dalam rangka memperkenalkan daya tarik wisata alam yang ada di Malino. Program ini merupakan program pengembangan pariwisata melalui kompetisi, karnaval dan pertunjukan musik modern serta berbagai kegiatan lainnya yang semuanya hanya dilaksanakan di daerah Malino, Kabupaten Gowa, Provinsi Sulawesi Selatan (Hijrah, 2019).

Malino merupakan kawasan yang dikenal dengan atraksi wisata alam yang banyak serta udaranya yang sejuk karena letaknya yang berada di daerah pegunungan. Malino merupakan salah satu bagian dari Kabupaten Gowa yang terletak di Kelurahan Malino, Kecamatan Tinggimoncong yang daerahnya berbatasan langsung dengan Kabupaten Maros. Malino telah lama dikenal sebagai daerah wisata sejak zaman penjajahan Belanda dan pendudukan Jepang di Indonesia, sampai sekarang karena keindahan alam pegunungan serta hamparan hutan Pinus yang hijau yang menjadi daya tarik tersendiri bagi orang-orang terdahulu untuk singgah dan beristirahat di tempat ini. Seluruh daerah di tempat telah dijadikan sebagai daerah destinasi wisata alam karena pihak pemerintah serta masyarakat setempat yang dapat mengelolanya dengan baik. Bahkan dalam setiap tahunnya dapat ditemukan berbagai atraksi wisata alam baru, baik itu pemandangan alam maupun yang atraksi wisata buatan manusia (Bosra \& Ridha, 2018).

Selain keindahan alam dan udara sejuk yang dimilikinya, Malino memiliki peninggalan sejarah dan budaya yang masih dapat ditemukan sampai sekarang. Peninggalan bersejarahnya antara lain masih terdapatnya gedung yang digunakan sebagai gedung konferensi untuk Konferensi Malino I dan Malino II. Malino menjadi saksi yang terjadi pada tahun 19462002 yang membahas tentang pembentukan NIT (Negara Indonesia Timur) oleh Belanda, perundingan damai konflik Poso dan konflik Maluku (Bosra \& Ridha, 2018).
Peninggalan sejarah lainnya seperti gua Jepang dan Bunker peninggalan Jepang yang masih berdiri kokoh hingga saat ini (Syahrul, dkk., 2017). Selain peninggalan sejarah, terdapat pula peninggalan budaya yang masih dapat ditemukan sampai saat ini, di antaranya masih terdapatnya rumah adat yang pada masa terdahulu merupakan bagian dari anak kerajaan Gowa yang terletak di desa Bulu'tana, Kecamatan Tinggimoncong, Kabupaten Gowa yang masih termasuk dalam area wisata Malino yang disebut dengan "Kerajaan Bulu'tana." Kerajaan itu terdiri dari tiga buah rumah adat, yaitu Balla Lompoa, Balla Jambua, dan Balla Tinggia. Dari ketiga rumah adat tersebut, hanya tinggal dua rumah adat yang masih berdiri kokoh, yaitu Balla Lompoa dan Balla Jambua, sedangkan Balla Tinggia telah musnah dibakar oleh kolonial Belanda pada tahun 1965 (Syahrul, dkk., 2017).

Selain peninggalan kerajaan Gowa, budaya adat istiadatnya masih tetap dipertahankan oleh warga di desa Bulutana sampai saat ini, yaitu "Adat Sampulo Ruae yang berarti "Adat Dua

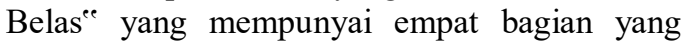
paling menonjol, yaitu Attompolo, Palili, Pabbuntingang dan Tu Kamateang (Sapri, 2016). Begitupun dengan peninggalan budaya, rumah adat yang ada di Malino kini sudah mulai tidak terurus, sedikit demi sedikit rumah peninggalan budaya kerajaan Buluetana itu terlihat kurang terawat tetapi masih kokoh berdiri sampai saat ini. Hanya saja akses yang jauh dari pusat kota Malino serta perjalanan yang hanya dapat ditempuh dengan jalan kaki atau dengan menggunakan kuda menjadikan rumah adat ini jarang dikunjungi oleh wisatawan dan jarang pula yang mengetahui keberadaannya kecuali masyarakat setempat (Syahrul, dkk., 2017).

Maka dari itu, diperlukan strategi dalam mengembangkan peninggalan sejarah dan budaya yang ada di Malino menjadi daya tarik bagi wisata sejarah dan budaya, sehingga peninggalan tersebut dapat tetap terpelihara serta dapat menjadi potensi wisata baru di Malino sebagai wisata sejarah dan budaya, dalam memperkenalkan sejarah yang pernah terjadi di Malino serta budaya yang masih dipelihara oleh warga setempat. Peninggalan sejarah dan budaya di Malino dapat dijadikan sebagai potensi dalam mengembangkan wisata sejarah dan budaya di Malino. Sekarang, semakin bertambahnya atraksi wisata baru dan belum adanya pengelolaan khusus pada peninggalan sejarah dan budaya di Malino menjadikan peninggalan tersebut kurang maksimal dalam berkembang dan banyak 
wisatawan yang tidak mengetahui akan peninggalan sejarah dan budaya di Malino.

Hal ini menjadikan tempat terjadinya sejarah yang ada di Malino menjadi tidak terawat, seperti telah ditumbuhi oleh semak belukar serta ditumbuhi oleh tanaman yang ditanami oleh warga sekitar, bahkan ada yang telah diubah menjadi tenda tempat warga sekitar untuk berdagang, seperti Gua Jepang yang ada di Malino. Selain itu, belum adanya program pengembangan untuk wisata sejarah dan budaya di Malino menjadikan potensi wisata sejarah dan budaya tersebut menjadi kurang dikenal oleh wisatawan yang berkunjung ke Malino, karena wisatawan lebih mengenal wisata alam yan ada di Malino daripada tempat yang memiliki nilai sejarah dan budaya yang ada di Malino. Lokasi yang jauh dan terpencil menjadi kendala para wisatawan untuk datang ke tempat-tempat bersejarah tersebut karena jauh dari pusat wisata alam Malino yang penuh akan atraksi-atraksi wisata, serta penginapanpenginapan menjadikan wisatawan lebih memilih untuk tinggal dan menikmati swafoto dengan latar belakang pemandangan hutan Pinus Malino.

Berdasarkan penjelasan diatas, maka keseluruhan fenomena yang terjadi pada peninggalan sejarah dan budaya di Malino dapat disimpulkan bahwa pada daya tarik wisata sejarah dan budaya itu belum adanya pengelolaan yang baik mengenai peninggalan sejarah dan budaya di Malino sebagai salah satu obyek wisata, obyek wisata alam di kawasan wisata Malino yang lebih dulu dikenal oleh kalangan wisatawan, atraksi wisata yang ada di obyek wisata alam di Malino lebih menarik perhatian wisatawan. Perhelatan event wisata Beautiful Malino 2019 yang digelar Dinas Pariwisata dan Kebudayaan Pemkab Gowa akan kembali digelar pada 12 hingga 14 Juli 2019 mendatang.

Setelah sukses di tahun pertama dan kedua, kini kemeriahan dan keseruan agenda tersebut akan kembali disuguhkan di tahun ketiga dan tentunya lebih berbeda dari sebelumnya. Plt Kabag Humas dan Kerjasama Setkab Gowa, Abdullah Sirajuddin mengatakan, beragam kegiatan dan lomba menarik telah disiapkan untuk memeriahkan event pariwisata tahunan ini. Salah satunya lomba sepeda gunung bertajuk "Malino International Mountain Bike." Rencananya pemenang atau juara umum pada kegiatan tersebut akan diikutsertakan pada event yang sama di Asia.Selain itu, juga akan diramaikan dengan parade bunga yang tahun ini mengambil tema " Flora dan Fauna". Parade ini akan diikuti seluruh SKPD, Kecamatan, dan organisasi pemerintahan lingkup Pemkab Gowa.

\section{KESIMPULAN}

1. Beautiful Malino setidaknya memberikan dampak yang positif terhadap sektor pariwisata di Sulawesi Selatan khususnya di Kabupaten Gowa.

2. Beautiful Malino, belum memberikan dampak signifikan terhadap sejumlah objek wisata sejarah dan budaya yang terdapat di Kota Malino. Hal ini disebabkan karena tidak terawatnya situs-situs sejarah dan budaya yang ada di kawasan Malino.

3. Perlu adanya peningkatan infrastruktur pendukung seperti perbaikan jalan serta lainnya di kawasan wisata Malino yang menjadi pendukung.

\section{DAFTAR PUSTAKA}

Aprilian, Dwi Sandy. (2015). Tesis: Partisipasi Pemuda Dalam Musyawarah Perencanaan Pembangunan Desa (Musrenbang Desa) Di Desa Sidorejo Kecamatan Rowokangkung Kabupaten Lumajang. Jember: Universitas Jember.

H.A.R Tilaar. (2009). Kekuasaan dan Pendidikan: Manajemen Pendidikan Nasional dalam Pusaran Kekuasaan. Jakarta: Rineka Cipta.

https://makassar.tribunnews.com/2019/07/08/be autiful-malino-2019-dikemas-lebihmeriah-jangan-sampai-ketinggalan

https://gowakab.bps.go.id/.2019. Kabupaten Gowa Dalam Angka 2019.Diakses pada tanggal 1 Maret 2020

Jannah. (2016). Partisipasi Pemuda dalam Pengembangan Desa Wisata. Studi di Desa Wisata Brayut, Kelurahan Pandowoharjo, Kecamatan Sleman, Kabupaten Sleman. Yogyakarta Universitas Islam Negeri Sunan Kalijaga.

John M. Echols dan Hassan Shadily. (2000). Kamus Inggris Indonesia An EnglishIndonesia Dictionary. Jakarta : PT. Gramedia.

Pamungkas Riyadi Aji. (2017). Partisipasi Pemuda Karang Taruna Desa Ambarwinangun Dalam Menumbuhkan Karakter Tanggung Jawab Dan Karakter Peduli Lingkungan Guna Menciptakan Lingkungan Yang Sehat Dan Bersih 
Surakarta. Solo, Universitas Muhammadiyah.

Undang-Undang Nomor 40 Tahun 2009 tentang Kepemudaan.
Undang-Undang Nomor 10 Tahun 2009 tentang Kepariwisataan.

Rencana Pembangunan Jangka Menengah Daerah Kabupaten Gowa Tahun 20162021. BAPPEDA Kab. Gowa. 2016. 